\title{
Dose Adjustment Reason
}

National Cancer Institute

\section{Source}

National Cancer Institute. Dose Adjustment Reason. NCI Thesaurus. Code C82555.

The explanation given as to why a dosage was adjusted. 